(C) 2000 The Chemical Society of Japan

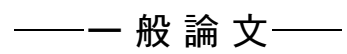

\title{
低温度か焼で得られた単斜晶および正方晶構造の 酸化ジルコニウムの表面酸塩基点の性質
}

\author{
(2000 年 7 月 17 日受理)
}

中 林 浩 俊

酸化ジルコニウムの結晶構造とその粒子表面に存在する酸点および塩基点の性質との関係を知るため, $450{ }^{\circ} \mathrm{C}$ 付近の低温度のか焼で単斜晶または正方晶の単一構造を有する試料をそれぞれ調製し，それらの 酸塩基触媒特性を比較した。

塩化酸化ジルコニウム水溶液をアンモニア水で加水分解するとき, 到達 $\mathrm{pH}$ 值を調節することで, 生 成する酸化ジルコニウムの結晶構造が異なり, pH 3 と pH 7 で調製した場合にはほぼ単一相の正方晶 と単斜晶がそれぞれ生成した．それらの単位表面積当たりの酸塩基量を測定したところ，いずれの構造 でもほぼ同等の酸塩基点の密度を示した. しかしながら, $\mathrm{NH}_{3}$ と $\mathrm{CO}_{2}$ の昇温脱離スペクトルから, 低 温度か焼で得られた単斜晶試料で強い酸点と塩基点の両方が存在することがわかった。さらに，1-ブ テン異性化反応では, 単斜晶構造の微粒子が最も高い活性を示すとともに, 反応の活性化エネルギーの 值も低くなることが判明した．この強い酸点と塩基点は, 単斜晶構造の酸化ジルコニウムの微粒子化に 伴う粒子表面の構造欠陥に起因するものと考えた.

\section{1 緒言}

酸化ジルコニウムは, その粒子表面に弱酸点と弱塩基点の両方 を同時に有することが報告されており，すぐれた触媒活性と反応 選択性を持つ酸塩基両機能触媒としての応用が期待されてい る1)-3). しかしながら, 酸化ジルコニウムの粒子表面の酸点や塩 基点の強度は非常に弱く, 広く触媒反応に応用するためには，そ れらの強度をより強くする必要がある。 そのため, それらの性質 を強化する目的で, 酸化ジルコニウムに別の金属イオンを添加し たり (4)-6), シリカなどの高表面積を有する担体に酸化ジルコニウ ム粒子を高分散するなどの手法がとられている7 ${ }^{7)}$. しかし多く の場合に抢いて， $\mathrm{Zr}^{4+}$ イオンと添加金属イオンとの相互作用な ぞが原因で，酸性質は保持されるものの，塩基性質が選択的に失 われている.

触媒として利用される酸化ジルコニウムは，一般に $\mathrm{ZrOCl}_{2}$ や $\mathrm{ZrO}\left(\mathrm{NO}_{3}\right)_{2}$ などのジルコニウム塩や $\mathrm{Zr}\left(\mathrm{OC}_{3} \mathrm{H}_{7}\right)_{4}$ などの金属ア ルコキシドを加水分解し, 得られた水酸化物を $400{ }^{\circ} \mathrm{C}$ から $800{ }^{\circ} \mathrm{C}$ でか焼して調製する。これらの温度範囲でか焼して得られた酸化 ジルコニウムの結晶構造は, 通常 $650{ }^{\circ} \mathrm{C}$ 以下の低温度では準安 定性正方晶系が主であり, それ以上の温度から徐々に単斜晶系の 構造へと転移するため, 2 種類の結晶の形態が混在した相を形成 する ${ }^{9)}$. 酸化ジルコニウム触媒のか焼温度と 1 -ブテンの異性化

高知工業高等専門学校物質工学科，783-8508 南国市物 部乙 $200-1$
反応における触媒活性の関係を調べた報告 ${ }^{10)}$ があるが， $800{ }^{\circ} \mathrm{C}$ 付 近のか焼で得られた酸化ジルコニウムが比較的高い触媒活性とよ い酸塩基特性を示している.このことは, 単斜晶系に完全転移し た構造の酸化ジルコニウムがより高活性であることを示唆する.

以前に著者は，酸化チタンや酸化スズなどの金属酸化物を微粒 子化すると, 非常に強い酸点が発現し, 酸強度が酸化物の粒子径 に依存することを見いだしている11-13)。そのため，酸化ジルコ ニウムの場合も微粒子化によって, 酸塩基点の強度がさらに強く なることが考えられる.しかし，微粒子を調製するには，少なく とも焼結や結晶成長が進行しないような低温度でか焼することが 必要である.

本研究では，より強い酸点と塩基点を有する酸化ジルコニウム を調製することを目的として，加水分解時に扔ける調製条件を幾 つか選択し, より低温度のか焼で単斜晶構造の酸化ジルコニウム 微粒子を調製して，その粒子表面の酸点と塩基点の性質を調へ た. さらに正方晶構造の場合や参照触媒酸化ジルコニウムとも比 較して, 結晶の構造や大きさが与える酸塩基触媒特性への影響に ついて求めた.

\section{2 実験}

\section{1 酸化ジルコニウムの調製とその他使用した試料}

出発原料として塩化酸化ジルコニウム八水和物 $\left(\mathrm{ZrOCl}_{2} \cdot 8 \mathrm{H}_{2}\right.$ O)を用いた． $0.025 \mathrm{~mol}$ の塩化酸化ジルコニウム八水和物を 200 倍 $\mathrm{mol}$ の純水に溶解して水溶液とした後，かき混ぜながら所定 の $\mathrm{pH}$ に到達するまで $25 \%$ アンモニア水をゆっくり滴下した. 
滴下後の溶液の $\mathrm{pH}$ は, $\mathrm{pH} 3, \mathrm{pH} 7$ および $\mathrm{pH} 11$ とした。さら に，1時間攪拌を続けた後，沈殿物を沪過して，純水で十分洗浄

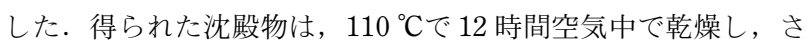
らに $350{ }^{\circ} \mathrm{C}$ か $5750{ }^{\circ} \mathrm{C}$ 温度範囲で 3 時間空気雾井気中でか焼し て酸化ジルコニウムを調製した.

また，調製した酸化ジルコニウムの物性等を比較するため，触 媒学会配布の参照触媒も使用した。使用した参照触媒は次のと抢 りである。酸化ジルコニウム JRC-ZRO, シリカーアルミナ JRC-SAH1 とSAL2, 酸化マグネシウム JRC-MGO-100.

\section{2 酸化ジルコニウムのキャラクタリゼーション}

調製した酸化ジルコニウムの結晶構造は, 粉末 X 線回折装置 (理学電機陎製 Geigerflex2028 型)を使用して観察した．X 線源 として $\mathrm{Cu} \mathrm{K} \alpha$ 線を用いて $2 \theta=20-40^{\circ}$ の範囲で測定した.

TG-DTA曲線は, 熱分析装置 (マックサイエンス製 TGDTA2020s 型)を用いて, 昇温速度 $10{ }^{\circ} \mathrm{C} / \mathrm{min}$ で空気気流中で測 定した。 また, 比表面積は, 迅速表面積測定装置(柴田科学器械 工業侏製 SA-1100 型)を用いて， $-196{ }^{\circ} \mathrm{C}$ に抢ける窒素吸着量か ら BET 法によって求めた.

\section{3 表面酸塩基性質の測定}

酸化ジルコニウムにおける粒子表面の酸点と塩基点の性質は, $150{ }^{\circ} \mathrm{C}$ での $\mathrm{NH}_{3}$ または $\mathrm{CO}_{2}$ の吸着量, およびそれら吸着ガスの 昇温脱離スペクトルで評価した.

まず， $0.1 \mathrm{~g}$ の酸化ジルコニウム試料を $\mathrm{He}$ ガス流通下で 400 ${ }^{\circ} \mathrm{C} て ゙ 1$ 時間か焼し, 前処理を行った. その後, 試料温度を $150{ }^{\circ} \mathrm{C}$ に保ち, 所定量の $\mathrm{NH}_{3}$ または $\mathrm{CO}_{2}$ の吸着ガスを飽和するまで試 料上に通じて，その吸着量をそれぞれ測定した。この $\mathrm{NH}_{3}$ の吸 着量を試料の酸量とし, $\mathrm{CO}_{2}$ の吸着量を塩基量とした.

さらに, $\mathrm{NH}_{3}$ または $\mathrm{CO}_{2}$ が飽和吸着した試料を流速 $100 \mathrm{~mL} /$ $\min$ のヘリウム気流中で $150{ }^{\circ} \mathrm{C}$ から $700{ }^{\circ} \mathrm{C}$ をで $10{ }^{\circ} \mathrm{C} / \min$ の速度 で昇温して, 試料から脱離するガスをガスクロマトグラフ装置 (秼島津製作所製 GC-6A)の TCD で検出することによって昇温 脱離スペクトルを観察した．このとき, 試料中に存在する水や表 面 $\mathrm{OH}$ 基などに起因する吸着分子以外の脱離分子によるスペク トルピークを除くため, $\mathrm{NH}_{3}$ や $\mathrm{CO}_{2}$ を吸着していない空実験試 料の昇温脱離スペクトルを同条件で測定し，さきのスペクトルと の差を計算することによって, $\mathrm{NH}_{3}$ および $\mathrm{CO}_{2}$ の昇温脱離スペ クトルを求めた.

\section{4 触媒活性の測定}

調製した酸化ジルコニウムの触媒特性を評価するためのテスト 反応として，1-ブテンの異性化反応を行った．反応には閉鎖型 循環系反応装置を用い, $140{ }^{\circ} \mathrm{C}$ か $5240{ }^{\circ} \mathrm{C}$ の温度範囲で反応を行

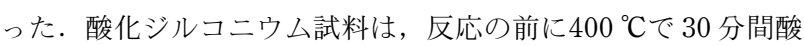
素気流中で加熱し, さらにその後同温度で 30 分間の真空排気処 理を行った，反応物の 1-ブテンの初圧は，およそ 110 Torr $(14.7$ $\mathrm{kPa})$ とし，生成物の cis-2-ブテンとtrans-2-ブテンおよび反応 物の 1-ブテンの組成比は, ガスクロマトグラフ装置(侏日立製作 所製 GC163)によって分析した。触媒活性は単位触媒量当たりの 初期反応速度で評価した. また, 異性化反応が一次の可逆反応で あるとして, 各反応温度に打ける速度定数を求め, それらの Arrhenius プロットから反応の活性化エネルギーを計算した.

\section{3 結果および考察}

\section{1 酸化ジルコニウムの構造}

ジルコニウム塩をアンモニア水で加水分解し, 得られた粉体を $400{ }^{\circ} \mathrm{C}$ で焼して調製した各酸化ジルコニウムの X 線回折パ ターンをFig. 1 に示す。比較のために, 参照触媒 JRC-ZRO に ついても示した．ジルコニウム塩をアルカリ溶液で加水分解した 場合, その加水分解時の到達 $\mathrm{pH}$ 值が， か焼後に得られる酸化ジ ルコニウムの結晶構造に影響を与えることが報告されてい る14)15)。本研究で調製した酸化ジルコニウムに抢いても，Fig. 1 に示すように加水分解時の到達 $\mathrm{pH}$ の值が異なると, 生成した酸 化ジルコニウムの X 線回折パターンにも違いが現れ，生成した 酸化ジルコニウムの結晶構造が，加水分解時の $\mathrm{pH}$ 值に影響を受 けることがわかる.

加水分解時の溶液の到達 $\mathrm{pH}$ を 3 に設定した場合では, $2 \theta=$ $30.1^{\circ}$ 付近に比較的強い回折ピークと $35.0^{\circ}$ 付近の比較的弱い ピークが現れた．これらの回折ピークは，酸化ジルコニウムの典 型的な正方晶構造に起因するものであり，pH 3 では，ほぼ単一 相の準安定性正方晶構造を有する酸化ジルコニウムを生成するこ

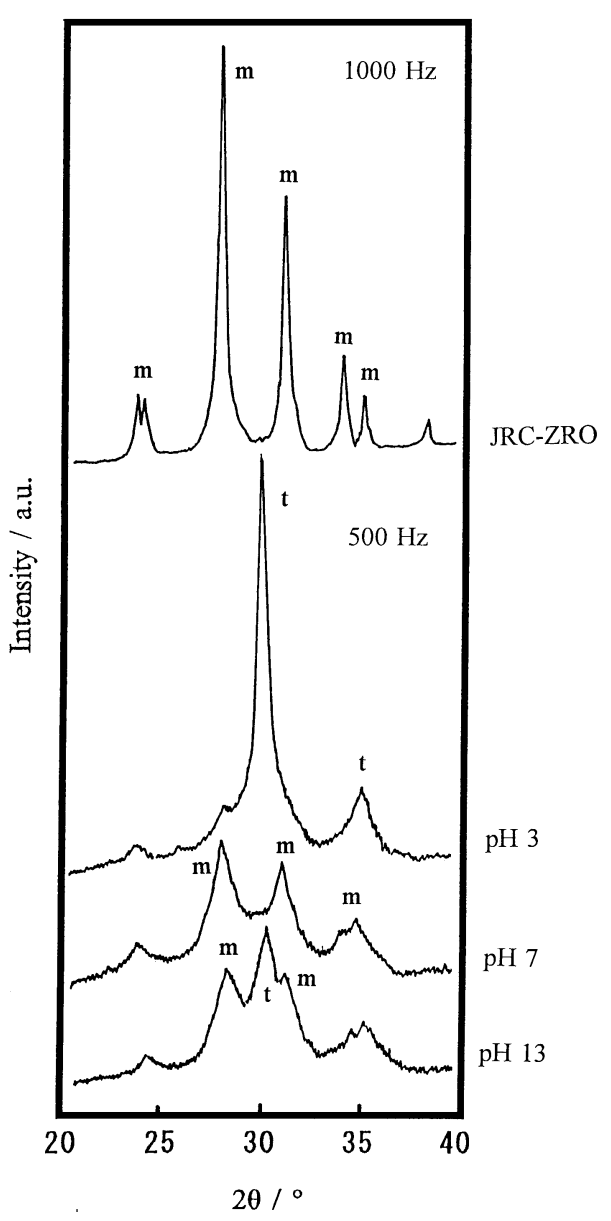

Fig. $1 \mathrm{X}$-Ray diffraction spectra of JRC-ZRO and $\mathrm{ZrO}_{2}$ prepared by hydrolysis at various $\mathrm{pH}$ solutions, calcined at $400{ }^{\circ} \mathrm{C}$.

$\mathrm{m}$ : Monoclinic, t: tetragonal. 
とがわかった。一方, pH 7 で調製した場合は, $2 \theta=30.1^{\circ}$ 付近 の回折ピークは観察されず，代わって $2 \theta=28.1^{\circ}$ と $31.4^{\circ}$ および $34.3^{\circ}$ 付近に 3 本の主なピークを観察した.これらは, 酸化ジル コニウムの単斜晶構造によるものであるが, その回折強度は比較 的弱く，また幅広くなっていることから，酸化ジルコニウムの結 晶子が小さくなっていると示唆される。したがって, pH 7 で調 製した場合は, ほぼ単一相の単斜晶構造を有する比較的小さな結 晶子の酸化ジルコニウムを形成することが判明した．さらに， $\mathrm{pH} 11$ の場合では, 主に 4 本の回折ピークが観察でき, これらの ピークから, 単斜晶と正方晶が混在する構造であることがわかっ た。 また, 比較用の JRC-ZRO 参照触媒の X 線回折パターンで は, pH 7 でか焼した酸化ジルコニウムと同じ位置に回折線を示 すことから，単斜晶構造であることが確認できるが，その回折 ピークの強度は, pH 7 の場合に比べて, はるかに強く, より大 きな結晶となっていることがわかる.

さらに, 異なる $\mathrm{pH}$ 值で加水分解して調製した各酸化ジルコニ ウムのか焼温度による結晶構造の変化を観察した結果を Fig. 2 から Fig. 4 にそれぞれ示す. Fig. 2 に示すように, pH 3 で調製 した酸化ジルコニウムでは, 350 から $450{ }^{\circ} \mathrm{C}$ のか焼温度範囲で準

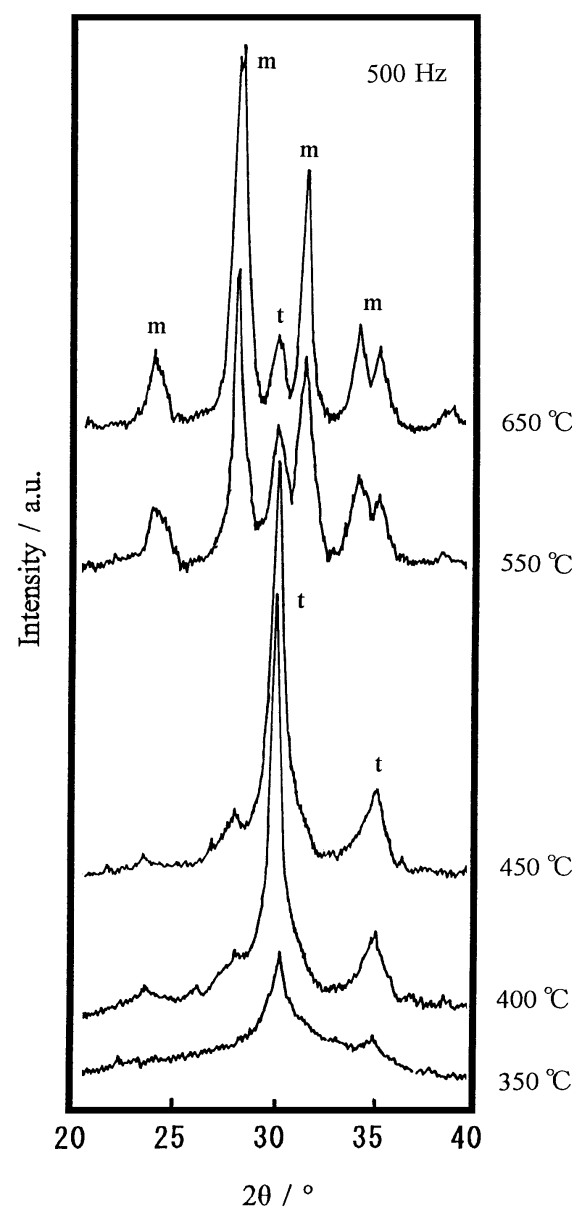

Fig. 2 Change in the $\mathrm{X}$-ray diffraction spectrum of $\mathrm{ZrO}_{2}$ prepared by hydrolysis at $\mathrm{pH} 3$ solution with the calcination temperature.

$\mathrm{m}$ : Monoclinic, t: tetragonal.
安定性の正方晶構造による回折ピークが観察できる.しかし, $550{ }^{\circ} \mathrm{C}$ 以上のか焼では, 正方晶による回折ピークは小さくなり, その代わりに強くてシャープな単斜晶による回折ピークが現れ た.このことは, pH 3 で調製した酸化ジルコニウムの構造は, か焼温度の上昇とともに，非晶質から準安定性正方晶になり，さ らにその正方晶が $550{ }^{\circ} \mathrm{C}$ 以上で単斜晶構造へと転移することを 示している.

一般に, 酸化ジルコニウム粒子の結晶構造は, か焼温度が 430 ${ }^{\circ} \mathrm{C}$ 以下ではほぼ非晶質であり, $430{ }^{\circ} \mathrm{C}$ から $650{ }^{\circ} \mathrm{C}$ の範囲で準安定 性正方晶が生成し, さらに $650{ }^{\circ} \mathrm{C}$ 以上の温度で単斜晶構造へと転 移することが知られている ${ }^{9)}$. 本研究で調製した $\mathrm{pH} 3$ の酸化ジ ルコニウムの構造変化 (Fig. 2) は，この一般的な報告 ${ }^{9}$ に比較的 よく一致するものである.

Fig. 3 には, pH 7 で加水分解して調製した場合の酸化ジルコ ニウムのか焼温度による構造変化を観察した結果を示した. 350 ${ }^{\circ} \mathrm{C}$ で焼した場合では, 回折ピークは観察されず非晶質である.

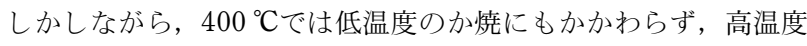
安定構造の単斜晶が生成し, 正方晶はほとんど観察できない。さ らにか焼温度を上昇させても, 回折ピークの位置には变化がな

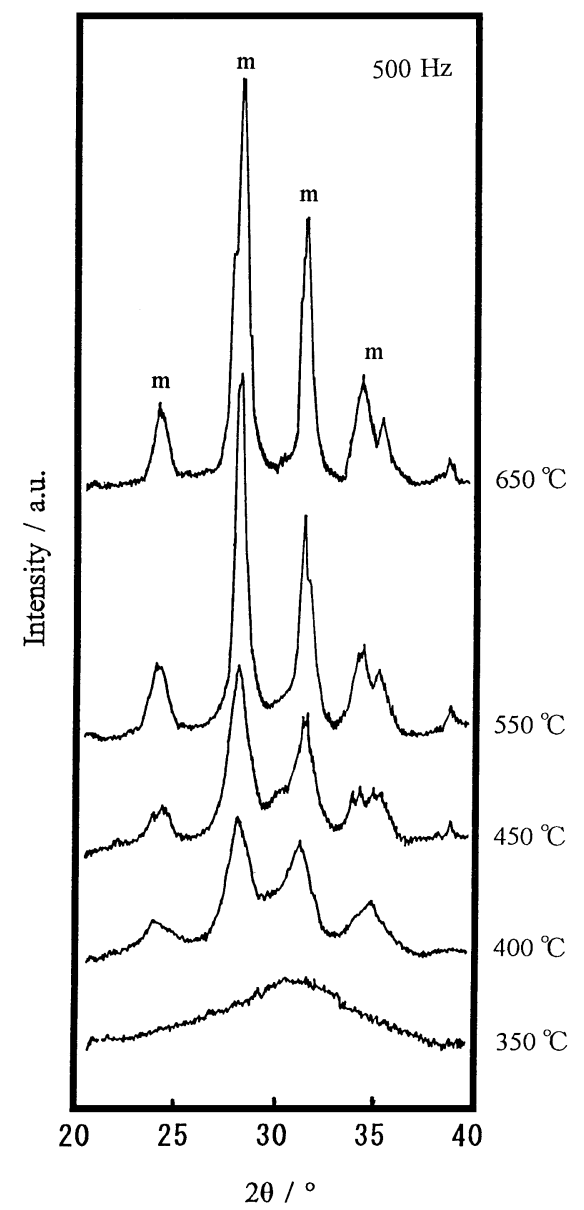

Fig. 3 Change in the X-ray diffraction spectrum of $\mathrm{ZrO}_{2}$ prepared by hydrolysis at $\mathrm{pH} 7$ solution with the calcination temperature.

$\mathrm{m}$ : Monoclinic, t: tetragonal. 


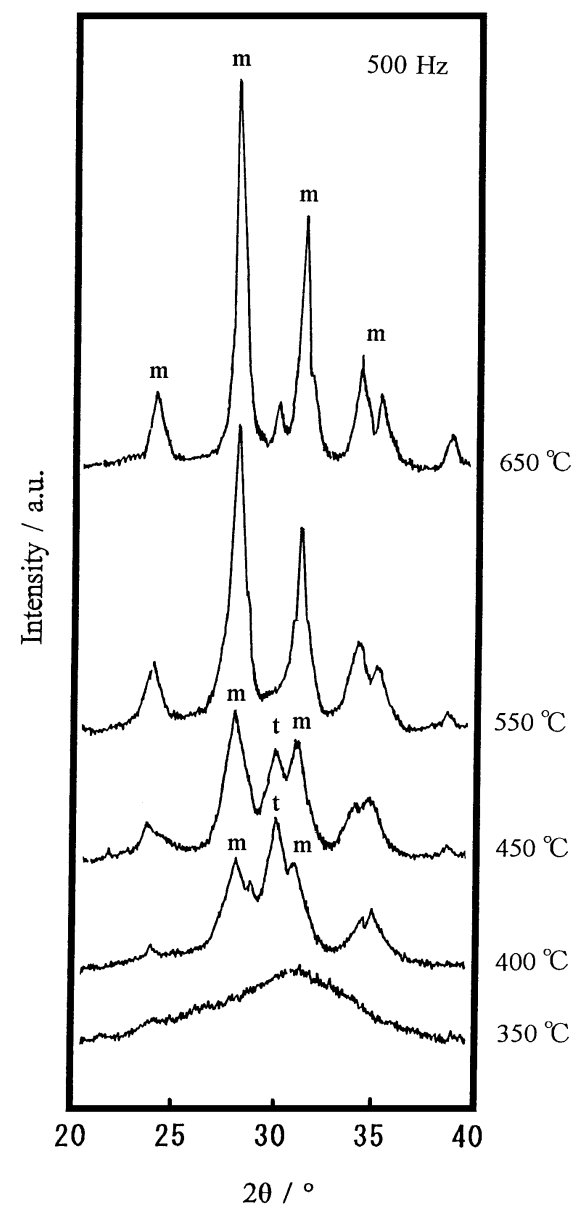

Fig. 4 Change in the $\mathrm{X}$-ray diffraction spectrum of $\mathrm{ZrO}_{2}$ prepared by hydrolysis at $\mathrm{pH} 11$ solution with the calcination temperature.

$\mathrm{m}$ : Monoclinic, t: tetragonal.

く, ピーク強度のみが強くなり, 単斜晶構造の結晶が温度上昇々 ともに成長することがわかる. したがって, pH 7 で加水分解し て得られた酸化ジルコニウム粒子の構造は, 非晶質から直接単斜 晶を形成することが判明した.

一方, pH 11で加水分解して得られた酸化ジルコニウムの場合 では，Fig. 4 に示すように， $350{ }^{\circ} \mathrm{C}$ か焼では非晶質であるが， $400{ }^{\circ} \mathrm{C}$ では正方晶と単斜晶の両方が混在した構造となった. さら にか焼温度の上昇させると, 正方晶が単斜晶へと転移し, $650{ }^{\circ} \mathrm{C}$ でか焼した場合は，ほぼ単斜晶構造のみとなった。 また， $650{ }^{\circ} \mathrm{C}$ 以上のか焼では, 加水分解時の $\mathrm{pH}$ の值にかかわらずすべての試 料に抢いて, 単斜晶構造の比較的強い回折線を示し, 単斜晶構造 への転移がほぼ完了した。

加水分解時における溶液の $\mathrm{pH}$ 值は, 生成した沈殿物を $400{ }^{\circ} \mathrm{C}$ から550 ${ }^{\circ} \mathrm{C}$ 付近の比較的低い温度範囲でか焼した場合において,

最終生成する酸化ジルコニウムの結晶構造の種類に強く影響を与 えることがわかった. 特に, 酸性側の $\mathrm{pH} 3$ で加水分解すると正 方晶の酸化ジルコニウムが生成し, 中性の $\mathrm{pH} 7$ では単斜晶の酸 化ジルコニウムが優先的に生成した. この原因は, 加水分解で沈 殿物として生成したジルコニウム水酸化物の構造の違いによるも
のと考えられる. ジルコニウム塩の加水分解で生成するジルコニ ウム水酸化物の構造には, $\mathrm{OH}$ の橋かけ結合の違いから, 三つの 種類が考えられている16). それらは, 高水和状態の $\alpha$ 型水酸化 物とその $\mathrm{OH}$ 基の一部が失われた $\beta$ 型水酸化物，およびさらに より多くの $\mathrm{OH}$ 基を失った $\gamma$ 型水酸化物である. 村瀬ら ${ }^{17)}$ によ ると, $\mathrm{Zr}$ に対する $\mathrm{O}$ の配位数の観点から, 高水和状態の $\alpha$ 型水 酸化物を熱処理すると正方晶酸化ジルコニウムが生成しやすく, 一方, 低水和状態の $\gamma$ 型水酸化物からは単斜晶酸化ジルコニウム が生成しやすいと報告している. 本研究で調製した $\mathrm{pH} 3$ 抢よび $\mathrm{pH} 7$ での加水分解生成物の TG 曲線を比較すると, pH 3 の方が 重量減少量が大きく, pH 7 の場合の 2 倍近くもあった.このこ とから, pH 3 での加水分解生成物は高水和状態の $\alpha$ 型水酸化物 であり, pH 7 の場合は低水和状態の $\gamma$ 型水酸化物となっている ものと推察される.

\section{2 粒子表面の酸塩基量}

$\mathrm{pH} 3$ 抢よび $\mathrm{pH} 7$ で加水分解して得られた沈殿物をか焼して 調製した正方晶と単斜晶構造のそれぞれの酸化ジルコニウム試料 について, 表面酸塩基特性を測定して結晶構造との関係を調べた.

Table 1 に $450{ }^{\circ} \mathrm{C}$ でか焼して得られた各酸化ジルコニウムの酸 量, 塩基量抢よび BET 比表面積の值を示す。 また，比較のため に酸触媒のシリカーアルミナ (JRC-SAH1, SAL2), 塩基触媒の 酸化マグネシウム (JRC-MGO-100)，打よび酸化ジルコニウム (JRC-ZRO)の各種参照触媒の測定結果も一緒にまとめた.ここ で, 酸量と塩基量は, $150{ }^{\circ} \mathrm{C}$ に打ける $\mathrm{NH}_{3}$ と $\mathrm{CO}_{2}$ の吸着量から 求め, 試料表面に存在する酸点または塩基点の一つのサイトに対 して 1 分子の $\mathrm{NH}_{3}$ または $\mathrm{CO}_{2}$ が吸着するものとしてそれぞれ算 出している11)18).

単位質量当たりの酸量を比較すると, 当然のことながら酸触媒 の JRC-SAH1 と SAL2 が $1.25 \mathrm{mmol} / \mathrm{g}$ と最も多い值を示した. しかしながら, 単位表面積当たりの酸量に換算すると, むしろ酸 化ジルコニウムの方が多くなり, 調製した 2 種の酸化ジルコニ ウム抢よび JRC-ZRO ともに $7-10 \mu \mathrm{mol} / \mathrm{m}^{2}$ 付近のかなり大き な值を示し, 酸点の密度が高いことがわかった。 また, 塩基量に おいては, 塩基触媒の JRC-MGO が単位質量および単位表面積 当たりともに最も大きな值を示したが，酸化ジルコニウムの塩基 量も比較的大きな值の $0.27 \mu \mathrm{mol} / \mathrm{m}^{2}$ を示した. すなわち, 酸化 ジルコニウムの粒子表面には, 酸点と塩基点の両方が比較的多量 に存在し, 酸と塩基の両方の特性を同時に有することが確認でき る.

そこで，調製した酸化ジルコニウムに注目して，さらに結晶構 造の違いによる酸量および塩基量への影響を観察した. pH 3 と pH 7 で調製した正方晶と単斜晶の各酸化ジルコニウム，および 参照触媒の JRC-ZROの酸量と塩基量をそれぞれ比較すると,

Table 1 に示すように，単位質量当たりではかなりの違いが見ら れるものの, 単位表面積当たりの換算では, 酸量と塩基量ともに 顕著な違いは観察されない。このことは, 酸化ジルコニウムの結 晶構造やその結晶の大きさの違いでは, 粒子表面の酸点や塩基点 の密度には影響しないことを示唆している.

さらに, Fig. 5 と 6 には, pH 3 と pH 7 で調製した正方晶と 単斜晶の各酸化ジルコニウムのか焼温度に対する単位表面積当た りの酸量と塩基量の変化をそれぞれ示す。いずれの構造において も，か焼温度が高くなるにしたがい，単位表面積当たりの酸量と 
Table 1 Acid and base amounts and surface areas of $\mathrm{ZrO}_{2}$ calcined at $450{ }^{\circ} \mathrm{C}$, and of reference catalysts

\begin{tabular}{|c|c|c|c|c|c|c|c|}
\hline Catalyst & $\begin{array}{l}\text { Crystal } \\
\text { structure }\end{array}$ & $\begin{array}{l}\text { Crystalline size } \\
\text { /nm }\end{array}$ & $\begin{array}{l}\text { Surface area } \\
\qquad / \mathrm{m}^{2} \mathrm{~g}^{-1}\end{array}$ & $\begin{array}{l}\text { Acid amount } \\
\text { per unit weight } \\
/ \mathrm{mmol} \mathrm{g}^{-1}\end{array}$ & $\begin{array}{l}\text { Acid amount per } \\
\text { unit surface area } \\
\qquad / \mu \mathrm{mol} \mathrm{m} \mathrm{m}^{-2}\end{array}$ & $\begin{array}{l}\text { Base amount } \\
\text { per unit weight } \\
/ \mathrm{mmol} \mathrm{g}^{-1}\end{array}$ & $\begin{array}{l}\text { Base amount per } \\
\text { unit surface area } \\
\qquad / \mu \mathrm{mol} \mathrm{m}^{-2}\end{array}$ \\
\hline $\mathrm{ZrO}_{2}-\mathrm{pH} 3$ & tetragonal & 12.6 & 39 & 0.301 & 7.5 & 0.0108 & 0.27 \\
\hline $\mathrm{ZrO}_{2}-\mathrm{pH} 7$ & monoclinic & 8.2 & 94 & 0.649 & 6.9 & 0.0235 & 0.25 \\
\hline JRC-ZRO & monoclinic & 19.3 & 16 & 0.155 & 9.7 & 0.0038 & 0.24 \\
\hline JRC-SAH1 & amorphous & - & 386 & 1.250 & 3.2 & 0.0025 & 0.0064 \\
\hline JRC-SAL2 & amorphous & - & 456 & 1.240 & 2.7 & - & - \\
\hline JRC-MGO-100 & - & - & 139 & 0.00162 & 0.012 & 0.272 & 1.96 \\
\hline
\end{tabular}

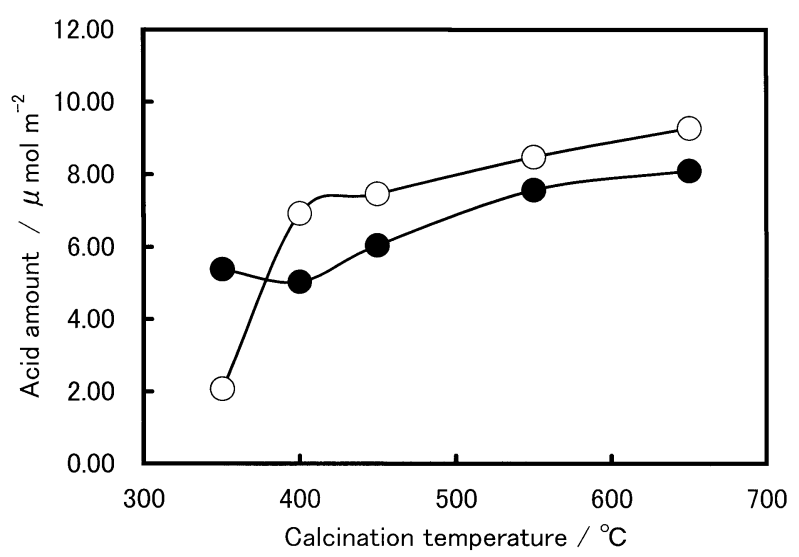

Fig. 5 Changes in the acid amounts per unit surface areas of $\mathrm{ZrO}_{2}$ prepared at $\mathrm{pH} 7$ and $\mathrm{pH} 3$ with the calcination temperatures.

○: $\mathrm{ZrO}_{2}-\mathrm{pH} 3$, O: $\mathrm{ZrO}_{2}-\mathrm{pH} 7$.

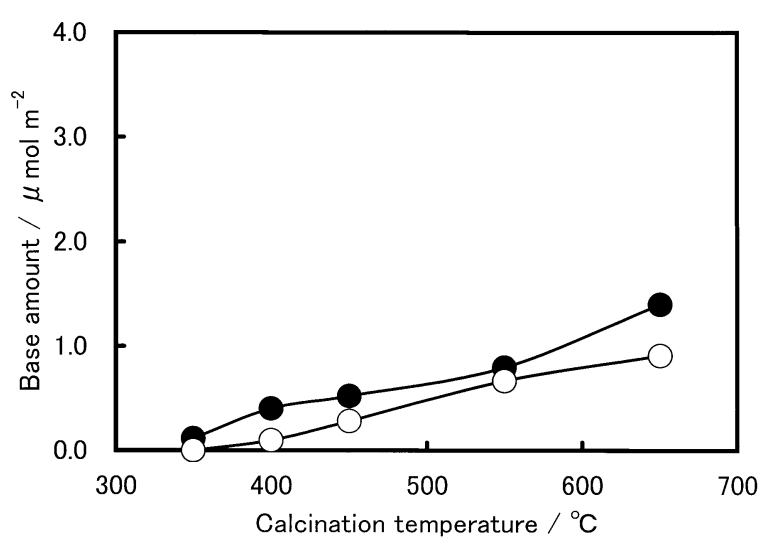

Fig. 6 Changes in the base amounts per unit surface areas of $\mathrm{ZrO}_{2}$ prepared at $\mathrm{pH} 7$ and $\mathrm{pH} 3$ with the calcination temperatures.

○: $\mathrm{ZrO}_{2}-\mathrm{pH}$ 3, $\bigcirc: \mathrm{ZrO}_{2}-\mathrm{pH} 7$.

塩基量は, ともにやや増加する傾向にある. しかしながら, 各か 焼温度に抢けるそれぞれの值を比較すると, 酸化ジルコニウムの 調製条件や結晶構造が異なってもほぼ同じくらいの值であり，や はり酸量・塩基量ともに結晶構造の違いによる顕著な差は観察で きなかった．これらのことから, 酸化ジルコニウムでは, その結

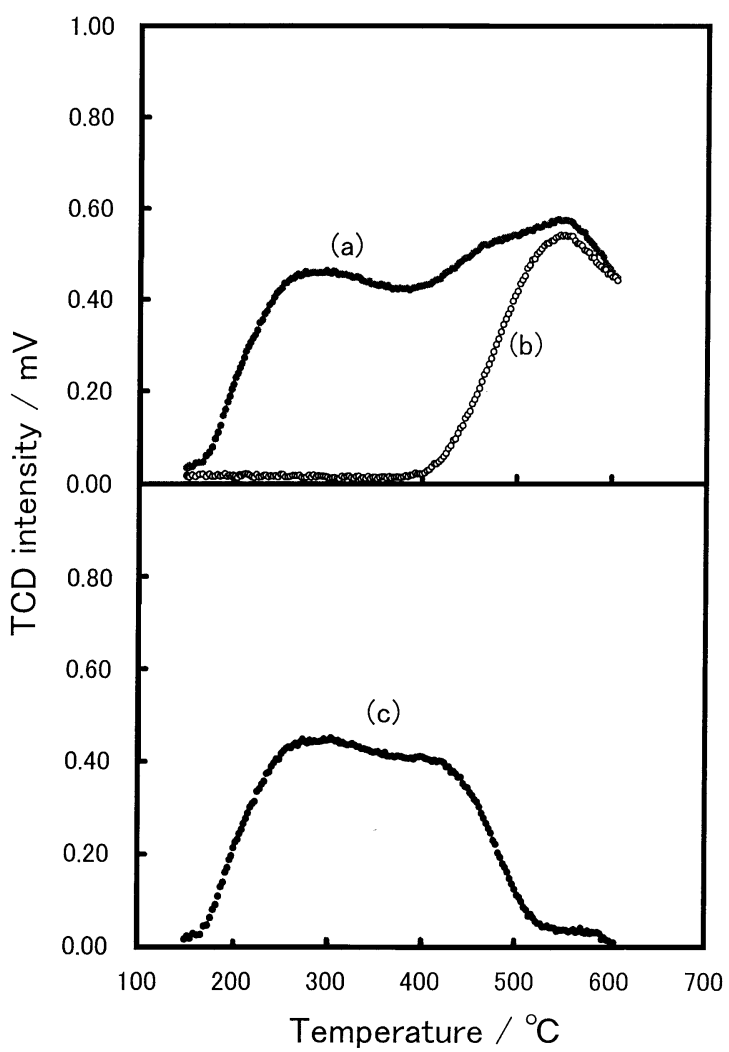

Fig. 7 Representative $\mathrm{NH}_{3}-\mathrm{TPD}$ spectrum (c) obtained by removal of blank spectrum (b) from desorption spectrum (a) of $\mathrm{ZrO}_{2}$ sample $\left(\mathrm{pH} 7,450{ }^{\circ} \mathrm{C}\right)$ adsorbed $\mathrm{NH}_{3}$ gas.

晶構造の種類やその大きさが異なっても，単位表面積当たりの酸 量や塩基量, すなわち粒子表面の酸点密度や塩基点密度にはほと んど影響しないことがわかる.

\section{3 粒子表面の酸点と塩基点の強度}

次に酸点や塩基点の強度についての情報を得るため, 各酸化シ ルコニウムに抢ける $\mathrm{NH}_{3}$ と $\mathrm{CO}_{2}$ の昇温脱離スペクトルを測定し た. 先述したように, 昇温脱離スペクトルは, $\mathrm{NH}_{3}$ または $\mathrm{CO}_{2}$ をあらかじめ吸着させた試料と吸着させない空実験試料との差入 ペクトルで求めている. Fig. 7 には, 代表的な試料として pH 7 で調製し $450{ }^{\circ} \mathrm{C}$ か焼で得られた酸化ジルコニウムの場合につい て, $\mathrm{NH}_{3}$ 吸着試料と空実験試料のそれぞれの脱離スペクトル, およびそれらの差スペクトルを示した。 


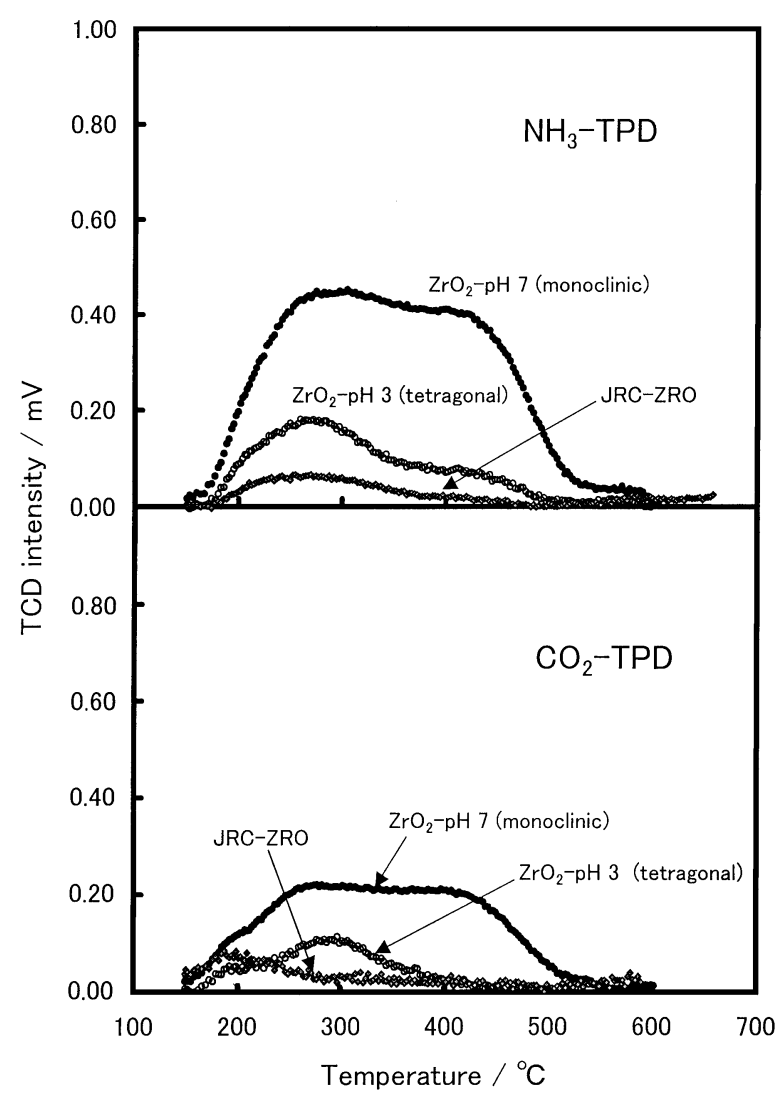

Fig. 8 TPD spectra of $\mathrm{NH}_{3}$ and $\mathrm{CO}_{2}$ adsorbed on monoclinic and tetragonal $\mathrm{ZrO}_{2}$ calcined at $450{ }^{\circ} \mathrm{C}$, and on JRC-ZRO.

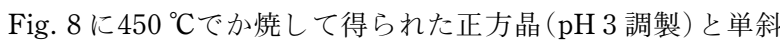
晶構造 ( pH 7 調製) の酸化ジルコニウム抢よび参照触媒 $\mathrm{JRC}-\mathrm{ZRO}$ の 3 種類の酸化ジルコニウムでの $\mathrm{NH}_{3}$ と $\mathrm{CO}_{2}$ の昇温 脱離スペクトルを測定した結果を示す．ここでは，上段に $\mathrm{NH}_{3}$ を吸着させた場合の昇温脱離スペクトルを示し，下段には $\mathrm{CO}_{2}$ の場合のそれを示している.

単斜晶構造の酸化ジルコニウム試料では, $\mathrm{NH}_{3}, \mathrm{CO}_{2}$ ともにか なり大きな脱離ピークが観察でき, 単位質量当たりでの酸量と塩 基量とも多いことがうかがえる. また, 単斜晶試料では, $\mathrm{NH}_{3}$ と $\mathrm{CO}_{2}$ の両脱離スペクトルともに, $270{ }^{\circ} \mathrm{C}$ 付近と $430{ }^{\circ} \mathrm{C}$ 付近に二 つのピークが存在した．この低温度側のピークは酸化ジルコニウ 厶粒子の表面に存在する比較的強度の弱い酸点あるいは弱い塩基 点に吸着した $\mathrm{NH}_{3}$ または $\mathrm{CO}_{2}$ の脱離によるものであり, 高温度 側のピークは強い酸点あるいは強い塩基点にそれぞれ吸着した $\mathrm{NH}_{3}$ または $\mathrm{CO}_{2}$ の脱離によるものである.したがって, 単斜晶 構造の酸化ジルコニウムでは, 粒子表面に強い酸点と弱い酸点, および強い塩基点と弱い塩基点を同時に有することがわかる.

一方, 正方晶構造の酸化ジルコニウムでは $\mathrm{NH}_{3}, \mathrm{CO}_{2}$ ともに ピーク総面積が小さく, 特に $400{ }^{\circ} \mathrm{C}$ 以上の高温度側では, $\mathrm{NH}_{3}$ で わずかなピークが観察されるものの， $\mathrm{CO}_{2}$ では高温度側には ピークは存在しなかった．このことは, 正方晶の酸化ジルコニウ ムには, 強い酸点や塩基点はほとんど存在しないことを示してい る. さらに参照触媒 JRC-ZRO に打いては, $\mathrm{NH}_{3}, \mathrm{CO}_{2}$ ともに低

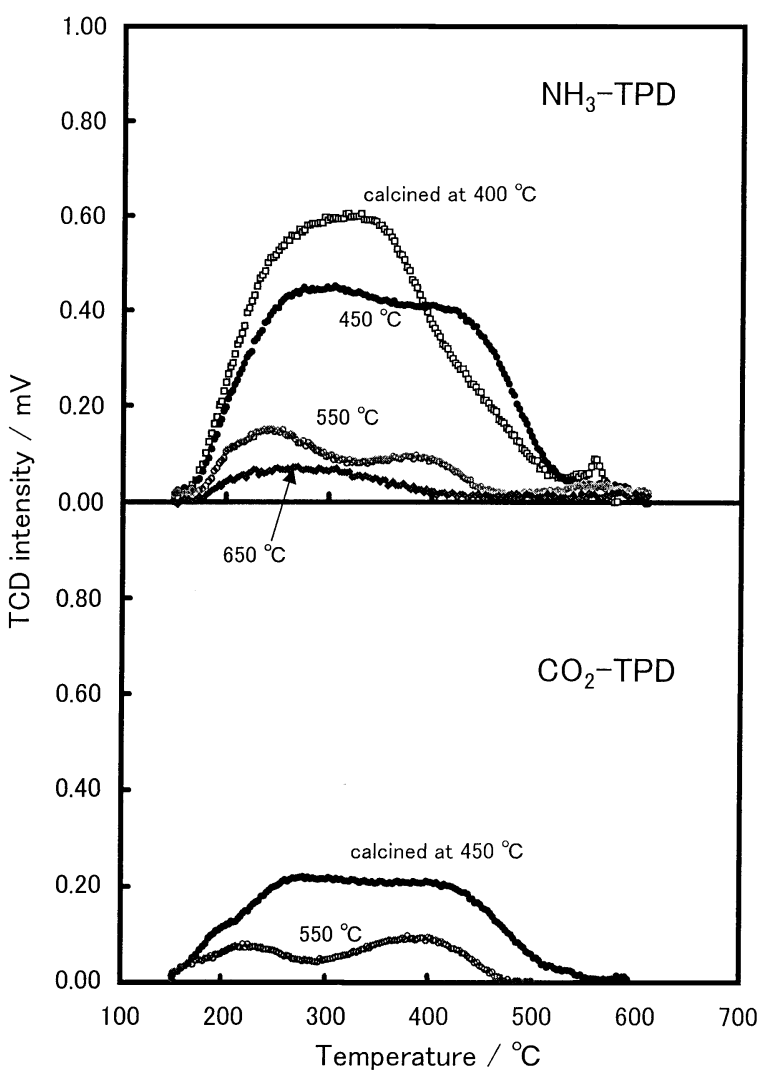

Fig. 9 TPD spectra of $\mathrm{NH}_{3}$ and $\mathrm{CO}_{2}$ adsorbed on monoclinic $\mathrm{ZrO}_{2}(\mathrm{pH} 7)$ calcined at various temperatures.

温度側の脱離ピークでさえも小さく, 特に $\mathrm{CO}_{2}$ での脱離ピーク は200 ${ }^{\circ} \mathrm{C}$ 付近のより低温度側にあり, 塩基点の強度も非常に弱く なっていることがわかった.これらの結果から, 調製した酸化ジ ルコニウム試料では, 結晶構造が異なると, その粒子表面の酸点 と塩基点の強度も著しく異なり, 結晶構造の違いが粒子表面の酸 強度や塩基強度に顕著な影響を与えることが判明した。

Fig. 9 に, pH 7 の加水分解で得られた酸化ジルコニウムのか 焼温度による $\mathrm{NH}_{3}$ 抢よび $\mathrm{CO}_{2}$ の昇温脱離スペクトルの変化をそ れぞれ示す. pH 7 で調製した単斜晶構造の酸化ジルコニウムに おける $\mathrm{NH}_{3}$ の昇温脱離スペクトルでは, Fig. 9 の上側に示すよ うに，か焼温度によってスペクトル曲線の形がかなり变化した。 $450{ }^{\circ} \mathrm{C}$ でか焼した試料の場合では, 先述したように, $270{ }^{\circ} \mathrm{C}$ 付近 と $430{ }^{\circ} \mathrm{C}$ 付近に二つのピークが観察でき, 強い酸点と弱い酸点の 2 種類の酸点が存在することがわかる. か焼温度を $550{ }^{\circ} \mathrm{C} に 上$ 昇 させると，その二つの脱離ピークは，かなり小さくなるととも に，ピーク位置もやや低温度側にシフトしている．このピーク位 置のシフトは, その酸点の強度が, か焼温度の上昇によって, 弱

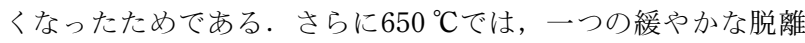
ピークのみとなり, Fig. 8 に示した JRC-ZRO の脱離スペクトル とほぼ同じ形状を示した.

一方， $400{ }^{\circ} \mathrm{C}$ のより低温度でか焼した試料では，およそ $320{ }^{\circ} \mathrm{C}$ 付近に一つのピークを持つ非常に大きなスペクトルを示したが， それより高温度側にはピークは存在しなかった．これは， $450{ }^{\circ} \mathrm{C}$ か焼の試料に存在するような強い酸点は発現せず，弱い酸点のみ 
Table 2 Activities for 1-butene isomerization on JRC-ZRO and $\mathrm{ZrO}_{2}$ catalysts calcined at $450{ }^{\circ} \mathrm{C}$

\begin{tabular}{|c|c|c|c|}
\hline Catalyst & $\begin{array}{l}\text { Activity for isomerization } \\
\text { at } 220^{\circ} \mathrm{C} \text { per unit weight } \\
/ \mathrm{mmol} \mathrm{min}^{-1} \mathrm{~g}^{-1} \text {-cat }\end{array}$ & $\begin{array}{l}\text { Activity for isomerization } \\
\text { at } 220^{\circ} \mathrm{C} \text { per unit surface area } \\
/ \mu \mathrm{mol} \mathrm{min}{ }^{-1} \mathrm{~m}^{-2} \text {-cat }\end{array}$ & $\begin{array}{l}\text { Activation energy } \\
\qquad / \mathrm{kJ} \mathrm{mol}^{-1}\end{array}$ \\
\hline $\mathrm{ZrO}_{2}-\mathrm{pH} 7$ (monoclinic) & 0.620 & 6.596 & 47.1 \\
\hline $\mathrm{ZrO}_{2}-\mathrm{pH} 3$ (tetragonal) & 0.109 & 2.792 & 80.5 \\
\hline JRC-ZRO & $0.00282^{a)}$ & $0.188^{\mathrm{a})}$ & 109.5 \\
\hline
\end{tabular}

a) The reaction was carried out at $240{ }^{\circ} \mathrm{C}$.

が多量に存在していることを示している，したがって，単斜晶構 造の酸化ジルコニウムの表面に存在する酸点は, $450{ }^{\circ} \mathrm{C}$ 以上の 温度でか焼した場合に強い酸点が存在し，その酸点はか焼温度の 上昇とともに強度も著しく弱くなることがわかった．特に $650{ }^{\circ} \mathrm{C}$ 以上でか焼した場合は, 強い酸点はほとんどなくなった。

酸化チタンなどの単独の金属酸化物の表面に存在する酸点は, 主にLewis 酸点であり，その強度は粒子径の減少とともに強く なることが報告されている(11)-13)19). $10 \mathrm{~nm}$ 程度の粒子径の金属 酸化物では, 表面部分に構造欠陥が多量に存在するため, 粒子表 面に局所的な電荷の不均衡が発生する．酸強度を強くする原因の 一つに, 粒子表面の構造欠陥の増加が挙げられている11)-13). す なわち, 酸化物粒子表面の構造欠陥の増加によって，その表面に 局所的な電荷の不足部分が発生し, それが強い酸点の発現に寄与 するものである.

本研究の pH 7 で調製した単斜晶の酸化ジルコニウムに抢いて も, Fig. 3 の X 線回折スペクトルに示すように, $450{ }^{\circ} \mathrm{C}$ のか焼で は非常にブロードなピークを示し，小さな結晶であることがわか る. 半值幅法でその結晶子径を求めると $450{ }^{\circ} \mathrm{C}$ か焼では約 $8 \mathrm{~nm}$ で, $650{ }^{\circ} \mathrm{C}$ では約 $20 \mathrm{~nm}$ であった。 また，それらの比表面積の

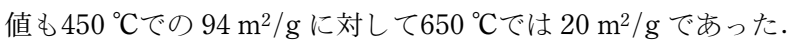
より低温度でか焼して得られた酸化物の粒子は, 粒子径が小さ く, 表面の構造欠陥もより多く存在する. そのため, 酸化チタン などの場合と同様に，酸化ジルコニウムに扔いても微粒子化によ ってより強い Lewis 酸点が発現するものといえよう. さらに付 け加えて, 酸化ジルコニウムの単斜晶構造は, 高温度では安定構 造であるが, $650{ }^{\circ} \mathrm{C}$ 以下の低温度では通常は正方晶構造の方が表 面エネルギーも小さくより安定である年20). それゆえ, 本研究で 調製したような $450{ }^{\circ} \mathrm{C}$ 付近の低温度のか焼で生成した場合の単斜 晶構造の粒子は, 構造的により多くの不安定性を持っており, 粒 子表面にも構造欠陥を多量に有するものと思われる. そのことに よっても, より強い酸点を有する原因となっているものと考えら れる.

ところで， $400{ }^{\circ} \mathrm{C}$ 以下でか焼した場合では，酸化ジルコニウ 么の粒子径もさらに小さくなるが, Fig. 9 の $\mathrm{NH}_{3}$ 脱離スペクト ルでは強い酸点は観察されない。一般に金属酸化物の粒子表面の 酸点は, 表面に存在する $\mathrm{OH}$ 基と深いかかわりがあり，か焼に よる $\mathrm{OH}$ 基の脱離で新しい Lewis 酸点が生ずるとも考えられて いる21). それは, $\mathrm{OH}$ 基の脱離に伴う粒子表面の構造欠陥の生成 が酸点に影響を与えることを示唆する。しかしながら， $400{ }^{\circ} \mathrm{C} 以$ 下のさらに低温度でか焼した試料では, 粒子表面に $\mathrm{OH}$ 基が脱 離せずにまだ残っているために，強い酸点が発現していないもの と推察される.

Fig. 9 の下側には, pH 7 で調製した単斜晶試料の $\mathrm{CO}_{2}$ の昇温
脱離スペクトルを示している. $\mathrm{NH}_{3}$ の脱離スペクトルの場合と 同様に， $450{ }^{\circ} \mathrm{C}$ と $550{ }^{\circ} \mathrm{C}$ でか焼した試料では，ともに二つの脱離 ピークが観察できるが，それぞれのピークの位置は，か焼温度の 上昇で，やや低温度側へのシフトが見られる．したがって, 塩基 点に抢いても，か焼温度の上昇によって，その強度が低下するこ とがわかる. $650{ }^{\circ} \mathrm{C}$ か焼の試料では, $\mathrm{CO}_{2}$ の吸着総量が少ない ため, 脱離スペクトルの観察はできなかった.

酸化物粒子表面に存在する塩基点は, 電子対供与性で説明され るため, 酸点の場合と同様に, 粒子の表面に生じた局所的な電荷 の過不足に起因するものである21)。さきにも述べたように，電 荷の過不足は, 表面の酸素原子や金属原子の欠損などに起因し, 酸化物の粒子径が減少するほぼ，その影響も大きくなる．塩基点 の場合でも, 微粒子による表面欠陥の増加が, 強い塩基点の発現 に寄与しているものと考えられる.

また, JRC-ZRO 参照触媒が単斜晶構造であるにもかかわら ず，非常に弱い酸点と塩基点しか有さないのも，650 ${ }^{\circ} \mathrm{C}$ 以上の高 温か焼の試料と同様に，より大きな結晶であり表面の欠陥が少な いためと説明できる.

\section{4 異性化活性と強酸塩基点}

$450{ }^{\circ} \mathrm{C}$ でか焼して得られた単斜晶と正方晶, および参照触媒 (JRC-ZRO)のそれぞれの酸化ジルコニウムを触媒として, 反応 温度 $220^{\circ} \mathrm{C}$ で 1-ブテンの異性化反応を行った結果を Table 2 に 示す。さらに，それぞれの触媒上での異性化反応における活性化 エネルギーを求めた Arrhenius プロットを Fig. 10に示す．Table 2 に示すように, 単斜晶構造の酸化ジルコニウムに打ける活 性が最も高く, 単位表面積当たりの活性でも $6.60 \mu \mathrm{mol} / \mathrm{min} \mathrm{m}^{2}$ -catで, それは正方晶構造の試料の $2.79 \mu \mathrm{mol} / \mathrm{min} \mathrm{m}^{2}$-cat に対 して約 2.5 倍も大きな值であった．また，参照触媒での活性は極 めて低く, $240{ }^{\circ} \mathrm{C}$ で応した場合でも単斜晶試料のおよそ $1 / 35$ の活性しかなかった，さらに，各触媒に扔ける異性化反応の活性 化エネルギーの值を比較すると，Fig. 10 に見られるように単斜 晶試料が最も小さな值を示した。これらのことから, 酸化ジルコ ニウムの構造の種類抢よび結晶の大きさの違いによって, 粒子表 面の活性点の性質が異なっていることがわかる.

1-ブテンの異性化反応では, 触媒粒子表面の酸点と塩基点が 活性点として作用するため，その酸点や塩基点の性質が反応の活 性に反映される ${ }^{10)}$. 単斜晶と正方晶抢よび参照触媒の 3 種類の 酸化ジルコニウム触媒では, さきの Table 1 で示したように, 単 位表面積当たりの酸量や塩基量, すなわち粒子表面に存在する酸 点や塩基点の密度に大差はないことから, 酸点と塩基点間の距離 についても大きな違いはない，それゆえ，反応活性の著しい増加 や活性化エネルギーの減少は, 触媒表面の酸点や塩基点の数, お よびそれらの密度や距離に関係するものではなく, 単斜晶の微粒 


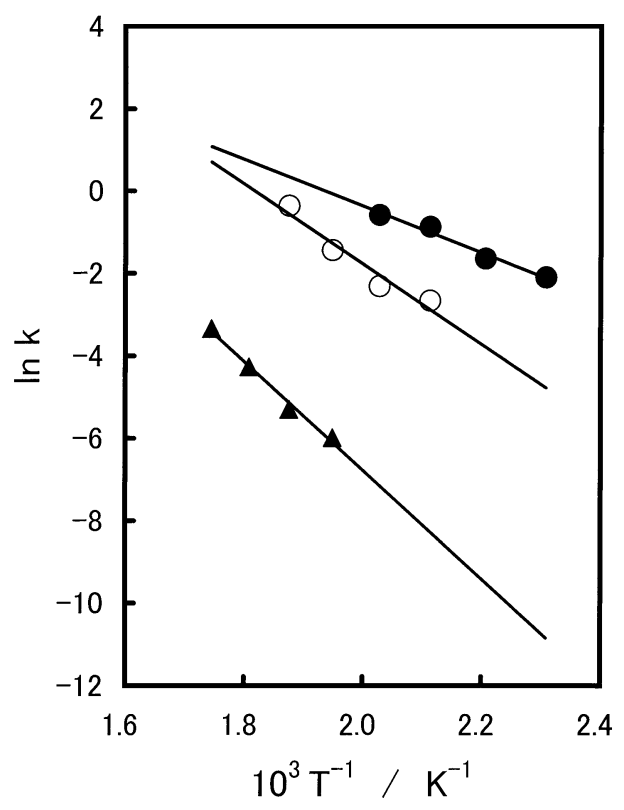

Fig. 10 Arrhenius plots for 1-butene isomerization on $\mathrm{ZrO}_{2}$ catalysts calcined at $450^{\circ} \mathrm{C}$, and on JRC-ZRO.

O: $\mathrm{ZrO}_{2}-\mathrm{pH} 7$ (monoclinic); $E=47.1 \mathrm{~kJ} / \mathrm{mol}$, $\bigcirc: \mathrm{ZrO}_{2}-\mathrm{pH} 3$ (tetragonal); $E=80.5 \mathrm{~kJ} / \mathrm{mol}$,

$\mathbf{\Delta}$ : JRC-ZRO; $E=109.5 \mathrm{~kJ} / \mathrm{mol}$.

子上に存在する酸点と塩基点の強度の増加に起因するものといえ る.したがって, Fig. 8 で示した昇温脱離スペクトルにおいて述 べたように， $450{ }^{\circ} \mathrm{C}$ でか焼して得られた単斜晶構造の酸化ジル コニウムの微粒子には，その表面に強い酸点と塩基点の両方を同 時に有することが，この1-ブテン異性化反応の活性や活性化工 ネルギーの值からも確認できる.

\section{4 結 論}

塩化酸化ジルコニウム水溶液をアンモニア水で加水分解すると き, 到達 $\mathrm{pH}$ 值を調節することによって, 最終的に生成する酸化 ジルコニウムの結晶構造の種類を制御することができる. pH 7 で調製した場合, $450{ }^{\circ} \mathrm{C}$ 付近の低温度でのか焼でも高温度安定 構造の単斜晶がほぼ単一相で生成する。一方 $\mathrm{pH} 3$ では準安定性 正方晶の単一相が， pH 11では両方の混合相が生成する.

pH 7 と pH 11でそれぞれ調製した単斜晶と正方晶の酸化ジル コニウムの酸塩基性質を比較しても, 単位表面積当たりの酸量や 塩基量に違いはなく, 粒子表面の酸点と塩基点の密度はどれもほ
ぼ同じである.しかしながら, 酸点と塩基点の強度に関しては, $\mathrm{pH} 7$ で調製し $450{ }^{\circ} \mathrm{C}$ でか焼して得られた単斜晶酸化ジルコニウ ムで強い酸点と塩基点の両方を示すが， $\mathrm{pH} 3$ で調製した正方晶 では弱い酸点と塩基点しか存在しない。また，pH 7 で調製した 単斜晶酸化ジルコニウムでも，か焼温度の上昇とともに酸点と塩 基点の強度は著しく弱くなり，粒子の成長が酸点や塩基点の強度 を低下させる．1-ブテンの異性化反応の活性では，強い酸点と 塩基点を有する単斜晶構造の微粒子が，最も高い活性を示し，さ らに反応の活性化エネルギーも小さい值を示す．低温度でか焼し て得られた微粒子で，かつ単斜晶構造を有する酸化ジルコニウム の場合に，その粒子表面に強い酸点と強い塩基点の両方が現れる ものと結論される.

1) T. Yamaguchi, Catal. Today, 20, 199 (1994).

2) 山口 力, 石油学会誌, 36, 250 (1993).

3) M. A. Aramendía, V. Borau, C. Jiménez, J. M. Marinas, A. Porras, F. J. Urbáno, J. Chem. Soc., Faraday Trans., 93, 1431(1997).

4) J. Fung, I. Wang, Appl. Catal. A: General, 166, 327 (1998).

5) Y. Hirashima, K. Nishiwaki, A. Miyakoshi, H. Tsuiki, A. Ueno, H. Nakabayashi, Bull. Chem. Soc. Jpn., 61, 1945 (1988).

6) V. V. Lunin, A. N. Kharlanov, Kinet. Catal., 37, 695 (1996).

7) J. B. Miller, E. I. Ko, J. Catal., 159, 58 (1996).

8) T. Yamaguchi, T. Morita, T. M. Salama, K. Tanabe, Catal. Lett., 4, 1(1990).

9）田部浩三，清山哲郎，笛木和雄，“金属酸化物と複合酸化 物”, 講談社 (1987) p. 119 ; 触媒学会編, “触媒講座 10, 触媒各論”, 講談社(1986), p. 61.

10) Y. Nakano, T. Iizuka, H. Hattori, K. Tanabe, J. Catal., 57, 1(1979).

11) H. Nakabayashi, N. Kakuta, A. Ueno, Bull. Chem. Soc. Jpn., 642428 (1991).

12) K. Nishiwaki, N. Kakuta, A. Ueno, H. Nakabayashi, J. Catal., 118, 498(1989).

13）中林浩俊，西脇克彦，角田範義，上野晃史，日化， 1991, 13.

14) B. H. Davis, J. Am. Ceram. Soc., 64, C-168(1984).

15) T. Tatsumi, H. Matsuhashi, K. Arata, Bull. Chem. Soc. Jpn., 69, 1191(1996)

16) L. M. Zaitsev, Zh. Neorg. Khim., 11, 1684(1966).

17）村瀬嘉夫，加藤悦朗，日化， 1978, 367.

18) H. Nakabayashi, Bull. Chem. Soc. Jpn., 65, 914 (1992).

19）中林浩俊，日化， 1992, 146 .

20）加藤昭夫, 荒井弘通, “超微粒子, その化学と機能”, 朝 倉書店 (1993), p. 4.

21）田部浩三，“触媒のはたらき”，増補改訂，化学同人 (1988), pp. 53, 65. 


\title{
Properties of Acid and Base Sites on Zirconium Oxides Having Monoclinic and Tetragonal Structures Formed by Calcination at Low Temperature
}

\author{
Hirotoshi NAKABAYASHI \\ Kochi National College of Technology; Monobe, Nankoku-shi 783-8508 Japan
}

A relationship between acid-base properties on $\mathrm{ZrO}_{2}$ catalysts prepared by hydrolysis of $\mathrm{ZrOCl}_{2}$ adjusted to various $\mathrm{pH}$ values with $\mathrm{NH}_{3}$ solution and their crystalline structures determined by XRD measurements was examined.

When the hydrolysis was carried out at $\mathrm{pH} 7$ and $\mathrm{pH} 3$, followed by the calcination at low temperature of $723 \mathrm{~K}$ in air, it was confirmed that the obtained $\mathrm{ZrO}_{2}$ had a simple structure of monoclinic and tetragonal, respectively.

The acid and base amounts per unit surface area of the $\mathrm{ZrO}_{2}$ were scarcely different in the type of the crystalline structures, indicating that the densities of acid and base sites present on the surfaces were not affected by the crystalline structures. However, the strength of both acid and base sites was found to significantly depend on the crystalline structures. The strong acid and base sites were observed in TPD spectra of $\mathrm{NH}_{3}$ and $\mathrm{CO}_{2}$ to appear on the monoclinic $\mathrm{ZrO}_{2}$ obtained by the calcination at low temperature, while only weak acid and base sites were observed on the tetragonal $\mathrm{ZrO}_{2}$ surface as well as on the monoclinic $\mathrm{ZrO}_{2}$ calcined at high temperatures. The higher specific activity and the lower activation energy for 1-butene isomerization were observed on monoclinic $\mathrm{ZrO}_{2}$ catalysts. It is suggested that the strong acid and base sites are formed on monoclinic $\mathrm{ZrO}_{2}$ with small particle size, and this is due to the structural defect. 